\title{
NOTES ON SOME AUSTRALIAN SPECIES OF CYPERACEAE
}

\author{
K. L. WILsON
}

(Accepted 27.11.1978)

\begin{abstract}
Wilson, K. L. (National Herbarium of New South Wales, Royal Botanic Gardens, Sydney, Australia 2000) 1980. Notes on some Australian species of Cyperaceae. Telopea 1 (6): 457-467,

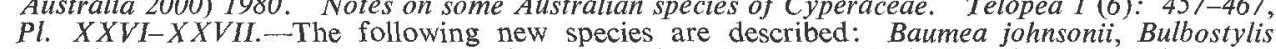
burbidgeae, Cyperus portae-tartari and C. viscidulus. Gahnia australis (Nees) K. L. Wilson and G. drummondii (Steud.) K. L. Wilson are published as new combinations and a key provided to Gahnia section Microstachyae. Cyperus lhotskyanus Boeck. is reinstated, and Lepidosperma exsul C. B. Clarke is relegated to synonymy under Tricostularia neesii Lehm. Cyperus compactus Retz. is recorded as new for Australia. A. key is provided to the Australian species of Bulbostylis, and B. eustachii J. M. Black ex C. M. Eardley is synonymized under B. barbata (Rottb.) C. B. Clarke.
\end{abstract}

\section{INTRODUCTION}

Recent collecting in Australia, particularly in the more remote northern areas, has provided material of new species and of little-known species of Cyperaceae.

In this paper, four new species are described and the synonymies of various other species are discussed. Since recent revisions exist for all but one of the genera dealt with here (Bulbostylis being the exception), discussion is brief. Of the revised genera, Kükenthal published revisions of Cyperus (1935-36), of Lepidosperma (1941 a \& b), of Baumea (1942) as a subgenus of Cladium, of Gahnia (1943) and of Tricostularia (1944). Gahnia had previously been revised by Benl (1940).

The work reported in this paper was begun at the National Herbarium of New South Wales and was completed after visits in 1977 to the Royal Botanic Gardens, Kew, to the British Museum (Natural History), to the Royal Botanic Gardens, Edinburgh, and to the Laboratoire de Phanérogamie, Paris.

Unless otherwise indicated, all specimens cited have been seen by the author.

\section{BAUMEA Gaudich.}

Baumea has been variously regarded as a subgenus of Cladium (Kükenthal, 1942), as a synonym of Machaerina (Kern, 1974; Vanhecke, 1974) and as a separate genus (Blake, 1969; Raynal, 1972). I am following Blake and Raynal in retaining Baumea as a separate genus.

Baumea johnsonii $K$. L. Wilson, sp. nov. habitu et inflorescentia B. gunnii (Hook. f.) S. T. Blake et affinibus similis et nullo dubio his speciebus proxima, praecipue culmis foliisque scabridis differt.

Holotype: New South Wales: Central Tablelands: Govetts Leap, Blackheath, E. F. Constable 5576 A, 10.xii.1964 (NSW). IsOTYPES: BRI, CANB, CHR, K, P.

Caespitose perennial. Culms erect, more or less terete to biconvex, scabrous, without nodes, $15-60 \mathrm{~cm}$ tall, 1-2 $\mathrm{mm}$ diam. Leaves basal, equitant, flattened above, to $150 \mathrm{~cm}$ tall, 2-3 $\mathrm{mm}$ wide, somewhat soft- to tough-textured, scabrous, shorter than to greatly exceeding culm and inflorescence; sheaths reddish; lowest leaves reduced to sheaths. Inflorescence-bracts reddish, flat, much shorter than lowest branch of inflorescence. Inflorescence paniculiform, (10-) 15-55 cm long, with (10-) 20-35 spikelets; branches slender, somewhat arching, sulcate, \pm scabrous; rhachis elongated between lowest and upper branches, sulcate, scabrous, (5-) 10-38 cm long. Spikelets 6-8 mm long, solitary, with 1 fertile flower, glumes 
spreading widely at maturity. Glumes 2 , linear-lanceolate, long-acuminate, $6-9 \mathrm{~mm}$ long, red-brown with paler nerves. Stamens 3; anthers 3.0-4.0 mm long, with an apical appendage c. $0.5 \mathrm{~mm}$ long. Style 3-fid. Nut ovoid to ellipsoid, deep golden brown to red-brown, becoming blackish, 2.5-3.5 mm long, strongly 3-costate when immature, sides convex between the costae; base narrow-pyramidal; style-base indistinct, pyramidal, umbonulate at maturity, slightly paler in colour, $0.7-0.8 \mathrm{~mm}$ long.

Distribution and Habitat: Confined to the Central Coast ranges and Central Tablelands of New South Wales. Found in permanently damp, sheltered positions below sandstone cliffs or along creeks.

Spectmens Examined: New South Wales: Central Coast: c. 1 mile [1.5 km] NW. of Bowens Creek on Mt Irvine road; Coveny NSW 123150, 10.1966 (NSW); Linden, Coveny NSW 123152, 11.1965 (NSW); Adelina Fălls, Lawson, Coveny 7739 \& Hind 7.1976 (NSW). Central Tablelands: Green Hill Gully, Mt Wilson, Gregson NSW 73952, 4.1902 (NSW); Coxs Cave, Mt Victoria, Constable 5727, 3.1965 (K, NSW); Govetts Leap, $2.4 \mathrm{~km}$ E. of Blackheath, Coveny 5996 \& Hind 1.1975 (NSW); Govetts Leap, Blackheath, Coveny NSW 12315I, 10.1966 (NSW); Bridal Veil Falls, Blackheath, Constable 6063, 8.1965 (NSW); Blackheath, Cheel NSW 73951, 12.1900 (NSW); Centennial Glen, $1 \frac{1}{2}$ miles [2.4 km] W. of Blackheath, Constable 4998, 9.1964 (NSW); Centennial Glen, Kanimbla Escarpment, Blackheath, Evans NSW 73949, 2.1927 (NSW); Popes Glen, Blackheath, Constable 6061,8.1965 (NSW); Valley of Waters, Wentworth Falls, Constable 5740, 3.1965 (NSW); Weeping Rock, Wentworth Falls, Constable 5743, 3.1965 (NSW); Carrington Falls, 17 miles [27 km] E. of Moss Vale, Constable 6257, 10.1965 (NSW).

The epithet is given in recognition of one of Australia's foremost plant taxonomists, Dr L. A. S. Johnson, whose wide-ranging studies of Australian plants have included Cyperaceae.

This species is closely related to $B$. gunnii (Hook. f.) S. T. Blake, B. muelleri (C. B. Clarke) S. T. Blake and B. nuda (Steud.) S. T. Blake but differs from them in having scabrous leaves and culms. The four species have very similar spikelets and inflorescence structure. They can be distinguished as follows:

1. Leaves flattened, $1.5-2.5 \mathrm{~mm}$ wide.

2. Leaves and culms scabrous. Leaf sheaths reddish. Nut $2.5-3.5 \mathrm{~mm}$ long, shortly stipitate $\ldots \ldots \ldots \ldots \ldots \ldots \ldots \ldots \ldots \ldots \ldots \ldots \ldots \ldots \ldots \ldots \ldots \ldots \ldots$, johnsonii

2.* Leaves and culms not scabrous. Leaf sheaths stramineous. Nut $3.0-3.5 \mathrm{~mm}$ long, with elongate stipe $\ldots \ldots \ldots \ldots \ldots \ldots \ldots \ldots \ldots \ldots \ldots \ldots, \ldots \ldots \ldots$, muelleri

$1{ }^{*}$ Leaves reduced to sheaths or terete $(0.5-1.5 \mathrm{~mm}$ diam.).

3. Leaves long, terete or \pm bisulcate, c. $0.5 \mathrm{~mm}$ diam. Nut c. $2 \mathrm{~mm}$ long. Slender plants with leaves usually much exceeding the inflorescence ............. B. nuda

3.* Leaves reduced to sheaths or long terete and then c. $1.5 \mathrm{~mm}$ diam. Nut $2.5-3.5 \mathrm{~mm}$ long. Stouter plants with leaves (when developed) as long as the inflorescence

B. gunnii

\section{BULBOSTYLIS Kunth, nom. cons.}

Bulbostylis burbidgeae $K$. L. Wilson, sp. nov. ab omnibus ceteris speciebus australiensibus spiculis valde squarrosis, glumis culmisque valde hispidis differt.

Holotype: Western Australia: Abydos Station, S. of Port Hedland, N. T. Burbidge 5876. 26.iv.1958 (NSW). IsOTYPES: BRI; CANB-not seen.

Annual herb. Culms erect to spreading, c. $4-25 \mathrm{~cm}$ tall, c. $0.5 \mathrm{~mm}$ diam., \pm terete below inflorescence but becoming biconvex towards the base, strongly and regularly 2-4-costate on each surface, hispid. Leaves basal with 1-2 cauline, 3-10 cm long, shorter than culms, channelled on smooth adaxial surface, flattened on abaxial surface with midrib prominent, $t$ hirsute; apex of sheaths hyaline, villous. Inflorescence-bracts 1-2 greatly exceeding inflorescence, filiform; the lower erect, 1-5 cm long; the upper shorter, erect or spreading. Inflorescence simple, 
consisting of 1-2 sessile spikelets often with 1-2 spikelets on rays; rays c. $2-10 \mathrm{~mm}$ long. Aerial spikelets solitary, pallid, squarrose, 5-15 $\mathrm{mm}$ long, 1-2 $\mathrm{mm}$ wide (excluding mucros), c. 8-24-flowered; rhachilla narrowly winged with a few scattered hairs. Subradical spikelets often present, similar in morphological features to aerial spikelets but borne on culms $<1 \mathrm{~cm}$ long. Glumes narrow-ovate to oblong, retuse to emarginate, $2.0-2.5 \mathrm{~mm}$ long, with prominent green keel; sides hyaline, pubescent; apex acuminate with a long recurved mucro $1.0-2.0 \mathrm{~mm}$ long, 1 nerve on each side close to keel. Stamens 3; anthers 1.0-1.8 mm long. Style 3-fid. Nut trigonous, narrow-obovoid to obovoid, $0.8-1.0 \mathrm{~mm}$ long, tricostulate, pustulate, glabrous, shiny, stramineous; style-base subglobose, persistent, $0.1 \mathrm{~mm}$ long.

Distribution and Habitat: Known from the Fortescue District of Western Australia; associated with rocky outcrops.

Specimens Examined: Western Australia: Gorge Creek, base of Gorge Range, Carolin 7640, 8.1970 (PERTH); Mt Edgar Station, Burbidge 1102, 6.1941 (BRI, PERTH-2 sheets).

The epithet is given in honour of the late Dr Nancy Burbidge, who contributed so greatly to our knowledge of the Australian flora.

B. burbidgeae is not closely related to any known Australian or Malesian species nor to any of the Madagascan species which I have seen.

Of the Australian and Malesian species, it is the only one with squarrose spikelets and more or less oblong glumes. It resembles $B$. pyriformis S. T. Blake and $B$. puberula (Poir.) C. B. Clarke in having pubescent glumes but differs from these species in glume colour, in the longer hairs on the glumes, in nut shape and surface, and in the shape of the style-base. In addition, it has a smaller inflorescence than B. puberula.

The subradical spikelets ("épis subradicaux" of Raynal, 1976) often found in this species and also in the other Australian species of Bulbostylis are not morphologically the same as the basal spikelets found in taxa which exhibit amphicarpy, such as Crosslandia (Fitzgerald, 1918), Eleocharis (Svenson, 1937), Schoenoplectus sect. Supini (Raynal, 1.c.) and some African species of Bulbostylis (Haines, 1971). Subradical spikelets are morphologically similar to aerial spikelets and differ only in being borne on shorter culms, whereas basal spikelets differ significantly from aerial spikelets in being composed of solitary female flowers in the axils of leaf-sheaths, with very long styles, usually producing nuts rather different from those produced aerially.

Bulbostylis barbata (Rottb.) C. B. Clarke in Hook. f., Fl. Br. India 6: 651 (1893); Kern, Fl. Malesiana, ser. 1, 7: 539 (1974).

Synonymy: Bulbostylis eustachii J. M. Black ex C. M. Eardley, FI. S. Australia, ed. 2: 945 (1957); synon. nov. HoLOTYPE: Pot plant, grown from seed collected between Everard and Musgrave Ranges, South Australia, by E. C. Black, J. M. Black (AD 95701007).

Examination of the holotype of Bulbostylis eustachii reveals that it belongs to B. barbata, a widespread species in Australia and throughout the Old World; also found in southern U.S.A. The holotype does differ in several respects from the common condition in $B$. barbata but specimens with corresponding differences can be readily found amongst the Australian material of this species. For example, the number of stamens per flower varies $(1-2)$ in the holotype and the anthers are c. 1.0 $\mathrm{mm}$ long whereas in $B$. barbata there is usually one stamen, with the anther c. $0.5 \mathrm{~mm}$ long. Similarly the nut is more broadly obovoid than, and without the sharply defined angles usually found in $B$. barbata.

The glumes are more pallid than is usual in $B$. barbata, which tends to have red-brown sides to the glumes, and the plants are more flaccid; but this variation can be accounted for by the stage of growth when collected and by conditions of growth. Such variation is a common consequence of cultivation and has no great significance. 
The Australian species of Bulbostylis can be distinguished as follows:

1. Spikelets squarrose. Glumes $2.0-2.5 \mathrm{~mm}$ long with recurved mucro $1.5-2.0 \mathrm{~mm}$ long.

[Nut obovoid, pusticulate.] W.A................... B. burbidgeae K. L. Wilson

1.* Spikelets not squarrose. Glumes usually mucronulate.

2. Glumes $2.7-3.3 \mathrm{~mm}$ long, pubescent. Nut pyriform, $1.0-1.4 \mathrm{~mm}$ long. Qld., N.S.W., N.T............................... B. pyriformis S. T. Blake

2.* Glumes $1.5-2.5 \mathrm{~mm}$ long, glabrous (or occasionally with margins ciliolate or keel scabrous). Nut obovoid or turbinate, $0.5-1.1 \mathrm{~mm}$ long.

3. Inflorescence capitate. [Nut obovoid, smooth, minutely reticulate (isodiametric cells).] Qld., N.S.W., S.A., N.T., W.A.... B. barbata (Rottb.) C. B. Clarke

3.* Inflorescence anthelate, open, occasionally reduced to 1 sessile spikelet.

4. Nut turbinate, transversely wrinkled and reticulate (clongate cells). Stamens 3. Keel of glumes minutely antrorsely aculeate, scabrous. Qld., N.T., W.A..................... B. turbinata S. T. Blake

4.* Nut obovoid to broadly obovoid, minutely granulate, indistinctly transversely wrinkled. Stamens 2 . Keel of glumes smooth. Qld., N.S.W. ............................. densa (Wall. in Roxb.) Hand.-Mazz.

\section{CYPERUS L.}

Cyperus portae-tartari $K$. L. Wilson, sp. nov. inter species sectionis Pinnatorum culmis scabridis, inflorescentia relative grandi, spiculis brevibus, glumis parvibus quam nucis brevioribus distinguenda.

Holotype: QueEnsland: Burke District: Hells Gate, $17^{\circ} 27^{\prime} \mathrm{S}, 138^{\circ} 22^{\prime} \mathrm{E}$, S. Jacobs 1527 , 9.v.1974 (NSW). ISOTYPE: K.

Perennial (?), with fibrous roots. Culms erect, $25-30 \mathrm{~cm}$ high, c. $2 \mathrm{~mm}$ diam., subtrigonous, strongly antrorsely aculeate and scabrous to nearly smooth. Leaves exceeding culms, flat to narrowly V-shaped in section, keeled, somewhat septatenodulose, antrorsely aculeate and scabrous on margins and abaxial surface; sheaths pale above, reddish below. Inflorescence-bracts leafy, 4-9 exceeding the inflorescence, to $45 \mathrm{~cm}$ long, $\rfloor$ septate-nodulose, margins and abaxial surface antrorsely aculeate and scabrous. Inflorescence supradecompound, spreading, c. $8-15 \mathrm{~cm}$ long; primary rays c. $6-15$, flattened, scabrous, to $12 \mathrm{~cm}$ long; ultimate branches bearing subdigitate clusters of 2-12 spikelets. Spikelets 4-8-flowered, 2-5 mm long, \pm compressed. Rhachilla narrowly winged, deciduous either before or after the glumes fall. Glumes ovate, $1.4-2.1 \mathrm{~mm}$ long, with $1.2-1.5 \mathrm{~mm}$ interval between adjacent glumes on same side of rhachilla, spreading widely at maturity, golden to red-brown, with 3-5 lateral nerves and broad green keel continued in a recurved mucro of $0.2-0.5$ $\mathrm{mm}$, keel often antrorsely aculeate and scabrous. Stamens 3; anthers $0.7-0.9 \mathrm{~mm}$ long, with reddish appendage c. $0.2 \mathrm{~mm}$ long. Style 3-fid. Nut trigonous, obovoid, 1.2-1.5 mm long, exceeding body of glume, black. Plate XXVI.

Distribution and Habitat: Found in the sandstone ridges at the northern end of the Queensland-Northern Territory border and in Arnhem Land.

Specimens Examined: Queensland: see holotype. Northern Territory: Magela Creek, Dunlop 3366, 2.1973 (K, NSW); Deaf Adder Creek Valley, Olsen 2661, 5.1976 (NSW); Deaf Adder Gorge, Dunlop 4455, 2.1977 (NSW ex DNA); near Clyde R, McArthur $\mathrm{R}$ area, Craven 3499), 1.1976 (BRI); near (NW. of) Katherine, Blake 17485, 4.1947 (BRI).

This species belongs to Cyperus section Pinnati Kükenth.

The epithet is derived from the locality in which the holotype was collected. 
Plate XXVI.

D. Mackay del.

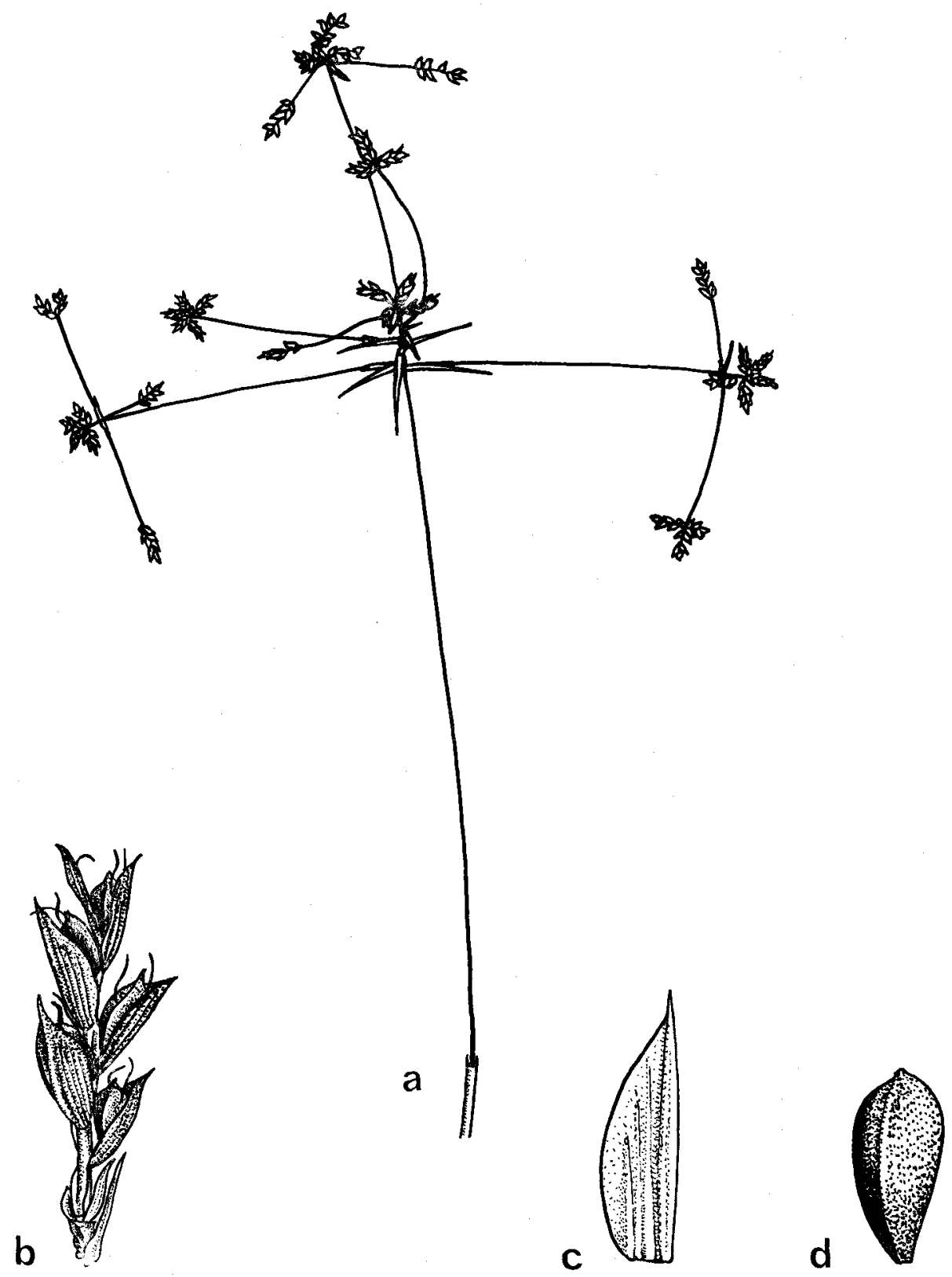

Cyperus portae-tartari K. L. Wilson

a. portion of inflorescence, $\times 1$. b. spikelet, $\times 10$. c. glume, $\times 20$. d. nut, $\times 20$ (from Jacobs 1527). 
Cyperus viscidulus $K$. L. Wilson, sp. nov. $C$. ixiocarpi F. Muell. affinis sed spiculis minus viscidis brevioribusque, glumis brevioribus sine mucrone longo differt.

Holotype: Western Australia: 15 miles [24 km] N. of Bow River Station, Kimberleys, M. Lazarides 5053, 15.iv.1955 (NSW). IsotYPES: BRI, CANB, K, P.

Perennial (?), with fibrous roots. Culms erect, 30-90 cm tall, 1-2 mm diam., subtrigonous to terete, smooth. Leaves flat to very narrowly V-shaped in section, equalling or exceeding culms, usually scabrous on margins and abaxial keel; sheaths pallid to purplish-red at base. Inflorescence-bracts leafy, 2-3 equalling to greatly exceeding inflorescence, to c. $45 \mathrm{~cm}$ long, usually scabrous on margins and keel. Inflorescence decompound to supradecompound, somewhat spreading, $5-15 \mathrm{~cm}$ long; primary rays c. $12-20$, to $13 \mathrm{~cm}$ long; ultimate branches bearing subdigitate clusters of 3-8 spikelets. Spikelets (5-) 8-16 (-28) -flowered, 4-12 mm long, $t$ compressed, viscid at maturity. Rhachilla occasionally minutely winged, deciduous either before or after the glumes fall. Glumes ovate, $1.7-2.3 \mathrm{~mm}$ long, $1.0-1.5 \mathrm{~mm}$ interval between adjacent glumes on same side of rhachilla, slightly curved dorsally, shortly mucronate (mucro c. $0.1 \mathrm{~mm}$ long), spreading widely at maturity, pallid to dark golden, with thickened keel and 2-3 nerves on each side. Stamens 3; anthers 0.6-1.0 $\mathrm{mm}$ long, with an inconspicuous reddish appendage c. $0.1 \mathrm{~mm}$ long. Style 3-fid. Nut trigonous, obovoid to ellipsoid, 1.7-2.0 $\mathrm{mm}$ long, subequal to glume, apiculate, black. Plate XXVII.

Distribution and Habitat: Known from the Northern Territory and the Kimberleys region of Western Australia; found beside streams and waterholes.

Specimens Examined: Western Australia: c. $6.5 \mathrm{~km} \mathrm{~W}$. of King R, S. side of Cockburn Range, Beauglehole 47240, 47242 \& Carr 7.1974 (MEL, NSW); Lennard R. Gorge, King Leopold Range, Carr \& Beauglehole 47753, 7.1974 (MEL); 13.5 miles [22 km] NW. of Elgie Cliffs Station, Lazarides 5103, 4.1955 (BRI, K., MEL); Windjina Gorge, Napier Range, Beauglehole 47687 \& Carr 7.1974 (MEL, NSW). NORTHERN TERRITORY: $70 \mathrm{~km}$ from Katherine near Ferguson R, Blake 16088A, 6.1946 (BRI, NSW); near McAdam Range, Mueller 10.1855 (MEL 75323).

The epithet refers to the stickiness of the mature spikelets.

This species is most closely related to Cyperus ixiocarpus F. Muell., differing from it in having shorter spikelets with the glumes more closely packed on the rhachilla. It also has smaller glumes without a prominent mucro.

These species, as well as $C$. portae-tartari K. L. Wilson, belong to Cyperus section Pinnati Kükenth. which contains 25-30 closely related species and has its greatest development in tropical and subtropical Australia. This section's closest affinity is with section Glutinosi Boeck. which has 7 species in South America and the Pacific Islands. The relationships of these sections will be discussed further in another paper on the taxonomic limits of the genus Cyperus sens. lat.

Cyperus compactus Retz., Obs. 5: 10 (1789); Kern, Fl. Malesiana, ser. 1, 7 : 638 (1974).

This distinctive species, which is widespread in Southeast Asia, has now been collected in tropical Australia. Mr P. Sharpe of BRI (pers. comm.) has seen two collections of this species from Ingham, Queensland. There is another collection from the Northern Territory and this is matched by the Malesian specimens cited below.

Specimens Examined: Australia: Northern Territory: Wagait Reserve, $13^{\circ} 12^{\prime} \mathrm{S}$, $130^{\circ} 40^{\prime} \mathrm{E}$, Dunlop 3132, 1.1973 (BRI, NSW; NT—not seen).

Malesia: Philippines: Leyte, Wenzel 1299, 5.1915 (NSW). Sarawak: Sandakan and vicinity, Ramos 1813, 9-12.1920 (NSW). Singapore: Gelang, Ridley 8.1900 (NSW 140336). 
Plate XXVII.

D. Mackay del.
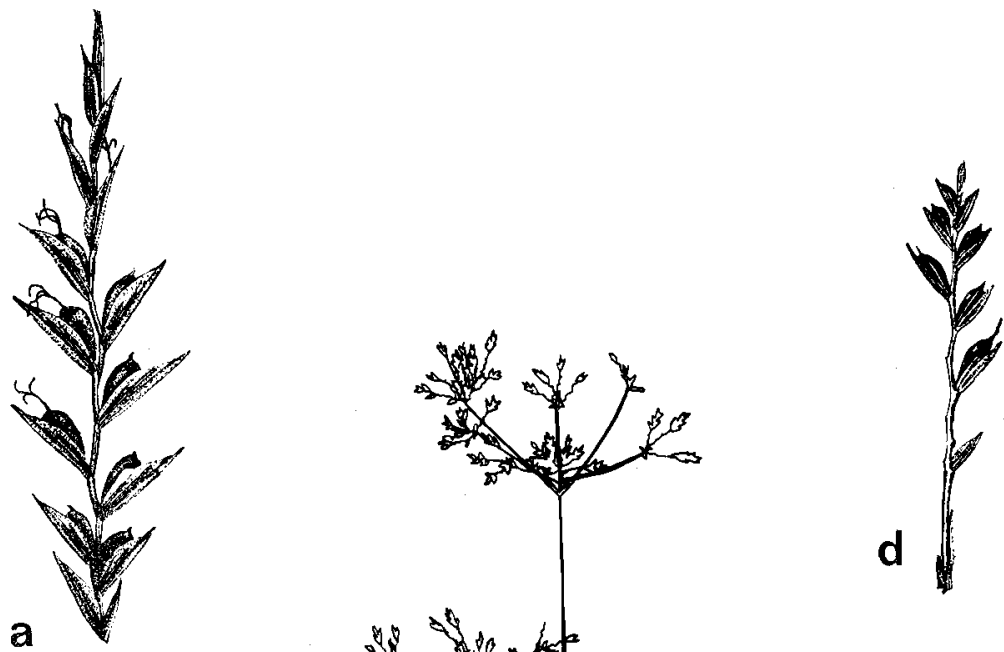

a
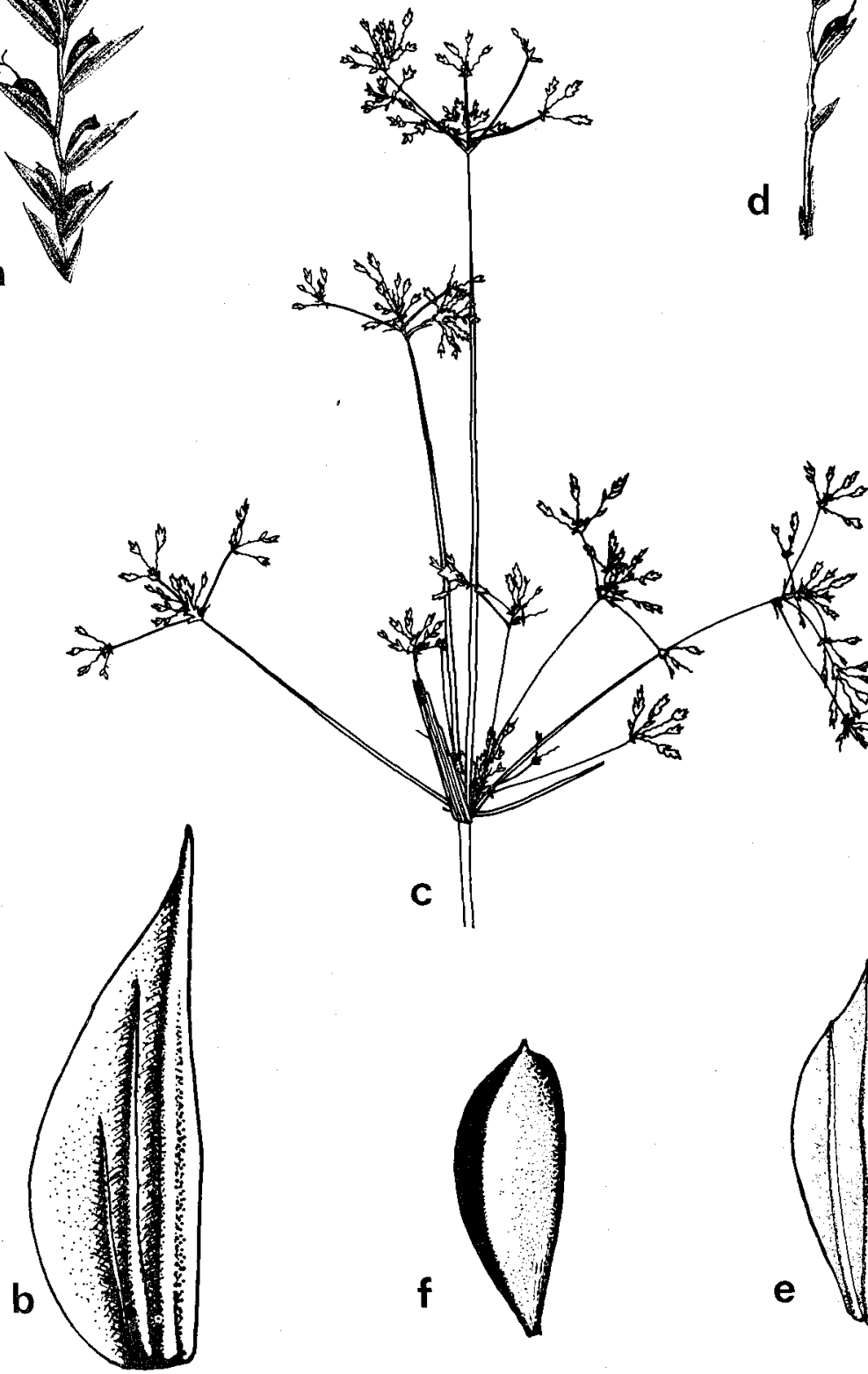

C

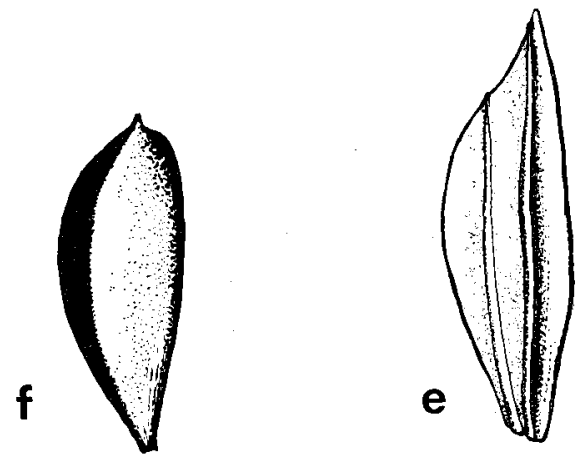

Cyperus ixiocarpus: a. spikelet, $\times 3$. b. glume, $\times 20$ (from Blake 8755). Cyperus viscidulus: c. inflorescence, $\times \frac{2}{3}$. d. spikelet $\times 3$. e. glume, $\times 20$. f. nut, $\times 20$ (from Lazarides 5103 ). 
Cyperus lhotskyanus Boeck. in Bot. Jahrb. Syst. 5: 498 (1884).

Holotype: Nova Hollandia, Lhotsky (KIEL).

Synonymy: Mariscus rutilans C. B. Clarke in Bull. Misc. Inform. 8: 18 (1908).-Cyperus rutilans (C. B. Clarke) Maiden \& Betche, Census New South Wales Pl.: 28 (1916); synon. nov. LeCTOTYPE (here designated): Armidale, Perrott [as 'Parrott'] (K).

Study of the type specimen of $C$. lhotskyanus showed it to be identical with the species hitherto known as $C$. rutilans and thus the former name is correct for this species. Kükenthal (1935-36) referred $C$. lhotskyanus doubtfully to the synonymy of $C$. subpinnatus Kükenth., an allied species.

The lectotype of $M$. rutilans C. B. Clarke is mounted on one sheet with a specimen of $C$. victoriensis C. B. Clarke and another specimen of C. Ihotskyanus (Liverpool Plains, Moore). On another sheet of C. lhotskyanus (Glenelg River, Robertson 561 (K)) Clarke has written "This is not exactly = Parrott's [sic] plant which I take as type of rutilans."

This species is found in New South Wales (South Coast and all Tablelands and Slopes divisions), Victoria and south-eastern South Australia.

\section{GAHNIA Forst. et Forst. f.}

Gahnia australis (Nees) K. L. Wilson, comb. nov.

Basionym: Elynanthus australis Nees, Ann. Mag. Nat. Hist. 6: 48 (1841); Nees in Lehmann [ed.], Pl. Preiss. 2: 79 (1846), p.p.

Holotype: Western Australia: Swan River, Drummond s.n. (CGE-photograph seen). IsOTYPE: $\mathrm{K}$ (photograph seen).

Synonymy: Baumea australis (Nees) S. T. Blake in Contr. Queensland Herb. 8: 28 (1969). -Cladium elynanthoides F. Muell., Fragm. 9: 31 (1875); Bentham, Fl. Austral. 7: 409 (1878) pro max. parte; nom illeg.-Gahnia elynanthoides (F. Muell.) F. Muell., Second Syst. Census: 216 (1889); nom. illeg.

This little-collected species has been known as Baumea australis (Nees) S. T. Blake. However, study of the original description and subsequent examination of specimens which have been referred to it showed that it belongs in Gahnia rather than in Baumea. It is referable to Gahnia section Microstachyae Kükenth. Its generic position is indicated not only by its superficial resemblance to the other species of sect. Microstachyae but also by its possession of the diagnostic characters necessary to put it into Gahnia (see Blake, 1969, p. 25). One of the obvious characters is possession of a leaf-ligule, which is membranous with a minute fringe of hairs in the holotype and isotype (B. Maslin, pers. comm.) and in Drummond 890 . Both Gahnia and Lepidosperma have ligules but $G$. australis differs from Lepidosperma in having a nut without inflated hypogynous scales.

Specimens Examined: Western Australia: Swan River, Drummond 890 (BM, K-photo seen, P).

No recent collections of this species have been seen by the author but PERTH has not been searched and it is possible that some specimens may be found there.

Nees in Lehmann (1846) cites two collections under his description of Elynanthus australis: "Ad flumen Cygnorum Novae Hollandiae Drummond in herb. Lindl." and "In glareosis sterilibus sylvae inter praedia rustica cll. Barker et Lennard, York, Apr. a. 1840. Herb. Preiss No. 1789". The former specimen is the type of $G$. australis; Preiss 1789 (BM, P) is not G. australis but G. lanigera (R. Br.) Benth., and differs from the common form of that species in having scaberulous culms and leaves (in which it is matched by Drummond 888 [P]). However, the Preiss specimen agrees in other significant characters with the common form of $G$. lanigera, as does Drummond 888. 
Gahnia drummondii (Steud.) K. L. Wilson, comb. nov.

BASIOnYm: Schoenus drummondii Steud., Synopsis Pl. Glum. 2: 165 (1855); non (Steud.) Benth. (1878). HolotyPe: Nova Hollandia, Drummond coll. IV 353, in herb. Steudel (P).

Synonymy: Gahnia polyphylla Benth., Fl. Austral. 7: 415 (1878). Lectotype (here designated): Swan River, Drurnmond 253, 1848 (K). IsolectotyPE: P. Benl (1940) designated Drummond 353 as lectotype of this name but his lectotypification must be set aside since Bentham did not cite that collection with the original description.

Examination of Steudel's herbarium in P showed that Gahnia polyphylla Benth. is synonymous with Schoenus drummondii Steud. Hence this species must now be known as Gahnia drummondii.

Specimens Examined: Western Australia: $6.6 \mathrm{~km}$ [4.1 miles] NW. of Wongan Hills towards Piawaning, Coveny 7833 \& Maslin $8.1976(\mathrm{~K}, \mathrm{NSW}$, PERTH $) ; 4 \mathrm{~km} \mathrm{~S}$. of Boxwood Hills, Newbey 4201, 6.1974 (NSW ex PERTH); -, Drummond 102 (K).

Steudel described this species as having flowers with three stamens, but the type specimen has six stamens as do the other specimens which I have examined.

Gahnia australis and G. drummondii belong in Kükenthal's section Microstachyae (Kükenthal, 1943). A revised key to the species of this section is presented below.

1. Leaf-sheaths with long-ciliate ligules (cilia obvious to the naked eye). [Leaf-bases dark brown-black.]

2. Leaf-bases dull.

3. Leaf tips erect, pungent-pointed. W.A....... G. aristata F. Muell. ex Benth.

3.* Leaf tips uncinate. W.A................. G. ancistrophylla Benth.

2.* Leaf-bases shining. [Leaf tips erect, pungent-pointed.]

4. Leaves scabrous. Glumes long-aristate, with margins densely ciliate (hairs may be lost with age). S.A., W.A................ G. deusta (R. Br.) Benth.

4.* Leaves smooth. Glumes shortly mucronate, glabrous. N.S.W., Vic., S.A., W.A.................................... lanigera (R. Br.) Benth.

1.* Leaf-sheaths with small membranous ligules bearing microscopic fringes of hairs.

5. Leaf-bases red-brown. Leaf-tips \pm uncinate. [Numerous cauline leaves.] W.A. ..................................... G. drummondii (Steud.) K. L. Wilson

5.* Leaf-bases dark brown to brown-black. Leaf tips erect.

6. Leaves scabrous, mostly basal but with 1-3 cauline. N.S.W., Vic., Tas. ....................................... microstachya Benth.

6.* Leaves smooth, all basal. W.A.......... G. australis (Nees) K. L. Wilson

\section{TRICOSTULARIA Nees}

Tricostularia neesii Lehm., Pugillus 8: 52 (1844); P1. Preiss. 2: 83 (1846).

Holotype: Habitat in Australia occidentali. (Herb. Preiss. no. 1728). Colitur in hort. bot. Hamburg (B? or S ?- not seen). IsOTYPE: MEL.

Synonymy: Lepidosperma exsul C. B. Clarke in Bull. Misc. Inform. 8: 47 (1908), synon. nov. Holotype: Swan River, Drummond no. 330 (G-DC—not seen). Isotype: K.

Lepidosperma exsul C.B. Clarke was included by Kükenthal (1941b) in his revision of Lepidosperma. However, examination of the isotype of this species in $\mathrm{K}$ revealed it to be a specimen of Tricostularia neesii.

The isotype, Drummond 330, bears a note written by C. B. Clarke: "Lepidosperma exsul C. B. Clarke ms in Drummond n. 330. This $\mathrm{n} .330$ was distributed inadvertently by Bentham to herb. DC $[==$ De Condolle $]$. I have never seen any piece but this; of which I lay in a scrap from herb. DC. Presented by M. DC. June 1894." 
Clarke's use of the word 'scrap' to describe the isotype is hardly reasonableit consists of several culms with inflorescences bearing somewhat immature achenes. However, I think that it is merely a case of misleading terminology and not a mixed specimen since the isotype agrees with both Clarke's and Kükenthal's descriptions of the species.

\section{ACKNOWLEDGEMENTS}

I wish to thank the Keeper of the British Museum of Natural History and the Directors of the Royal Botanic Gardens, Kew, of the Royal Botanic Gardens, Melbourne, and of the Laboratoire de Phanérogamie, Paris, for facilities and assistance offered to me during visits to their institutions.

Thanks are due to the Directors of the following herbaria for sending specimens on loan: AD, CANB, KIEL, PERTH.

The figures were drawn by Mr David Mackay.

Miss Sheila Hooper (K) and M. Jean Raynal (P) were most helpful during my visits to their respective institutions.

Mr Bruce Maslin kindly supplied me with information on, and photographs of, Drummond type specimens in CGE and $K$.

\section{LITERATURE CITED}

Benl, G., 1940--Die Systematik der Gattung Gahnia Forst. Bot. Arch. 40: 151-257.

Blake, S. T., 1940-Notes on Australian Cyperaceae III. Proc. Roy. Soc. Queensland 51: $32-50$.

Blake, S. T., 1947-Notes on Australian Cyperaceae VII. Proc. Roy. Soc. Queensland 58: $35-50$.

Blake, S. T., 1969-Studies in Cyperaceae. Contr. Queensland Herb. 8.

Fitzgerald, W. V., 1918-The botany of the Kimberleys, North-west Australia. J. \& Proc. Roy. Soc. Western Australia 3: 102-224.

Haines, R. W., 1971-Amphicarpy in East African Cyperaceae. Mitt. Bot. Staatssamml. München 10: 534-538.

Kern, J. H., 1974-Cyperaceae. Flora Malesiana, ser. 1, 7: 435-753.

Kükenthal, G., in A. Engler, 1935-36-Cyperaceae-Scirpoideae-Cypereae. Das Pflanzenreich IV 20 (Heft 101).

Kükenthal, G., 1941a-Vorarbeiten zu einer Monographie der Rhynchosporoideae X. Repert. Spec. Nov. Regni Veg. 50: 19-50.

Kükenthal, G., 1941b-Worarbeiten zu einer Monographie der Rhynchosporoideae XI. Repert. Spec. Nov. Regni Veg. 50: 112-128.

Kükenthal, G., 1942-Vorarbeiten zu einer Monographie der Rhynchosporoideae XII. Repert. Spec. Nov. Regni Veg. 51: 1-17, 139-193.

Kükenthal, G., 1943-Vorarbeiten zu einer Monographic der Rhynchosporoideae XIII. Feddes Repert. Spec. Nov. Regni Veg. 52: 52-111.

Kükenthal, G., 1944-Vorarbeiten zu einer Monographie der Rhynchosporoideae XV. Feddes Repert. Spec. Nov. Regni Veg. 53: 187-219. 
Lehmann, J. G. C. [ed.], 1844-48-Plantae Preissianae. Hamburg. 2 vols.

Raynal, J., 1972-Notes Cypérologiques 17-Révision des Cladium P. Browne s. lat. (Cyperaceae) de Madagascar et des Mascareignes. Adansonia, ser. 2, 12: $103-112$.

Raynal, J., 1976-Notes Cypérologiques 26-Le genre Schoenoplectus. II L'amphicarpie et le sect. Supini. Adansonia, ser. 2, 16:119-155.

Svenson, H. K., 1937-Monographic studies in the genus Eleocharis IV. Rhodora 39 (462): 210-231.

Vanhecke, L., 1974-Embryography of some genera of the Cladiinae and the Gahniinae (Cyperaceae) with additional notes on their fruit anatomy. Bull. Jard. Bot. Nat. Belg. 44: 367-400. 